\title{
Duelo por el padre y duelo por la patria. La poliatría en El olvido que seremos (2006), de Héctor Abad Faciolince
}

En 2006, casi dos décadas después del asesinato de su padre, Héctor Abad Faciolince publicó una novela sobre este crimen titulada El olvido que seremos. En la medida en que sugiere múltiples relaciones entre la familia y la nación, y entre el padre y la patria, el libro supone un importante análisis revisionista del reciente pasado colombiano. Al mismo tiempo estas relaciones - sobre todo de contraste - suscitan la pregunta de saber hasta qué punto la memoria construida por el escritor - que en principio se presenta como incomparable y literal - tiene un valor emblemático y colectivo. Por los temas que aborda, el libro incita asimismo a reflexionar en torno al papel que pueden desempeñar la belleza y el olvido en los procesos de duelo. En la presente contribución estudiaremos estos temas en la novela del escritor antioqueño, situándolos en el marco más general de las letras colombianas e hispanoamericanas contemporáneas que tratan de la violencia en el reciente pasado histórico.

El 25 de agosto de 1987 el médico y profesor de universidad Héctor Abad Gómez fue asesinado por dos sicarios en Medellín. Se solía llamar a sí mismo poliatra, un médico de la polis, y consideraba que su vocación era curar la epidemia de la violencia que azotaba a la sociedad colombiana. Como buen médico, diría posteriormente su hijo, pereció combatiendo la peste que en aquellos años se manifestaba bajo la forma de grupos paramilitares apoyados por ciertos actores estatales que execraban a los intelectuales poliatras. Héctor Abad Faciolince necesitó casi dos décadas para poder escribir sobre la muerte violenta de su padre y lo hizo en $E l$ olvido que seremos (2006), un texto que se encuentra en la encrucijada entre el testimonio (se centra en la sociedad colombiana de las décadas que van del sesenta hasta el asesinato), la saga familiar y las memorias (cuenta su propia historia, la de sus antepasados y sobre todo la de sus padres y hermanas) y la autoficción (hay identidad onomástica entre narrador, protagonista y autor, pero el libro fue publicado en la colección Biblioteca Breve de Seix Barral, con lo cual se presentó como un texto ficcional). ${ }^{1}$ 
Al tejer múltiples relaciones entre la familia y la nación, y entre el padre y la patria, el texto supone un importante análisis revisionista del pasado colombiano. ${ }^{2}$ Al mismo tiempo estas relaciones suscitan la pregunta de saber hasta qué punto la memoria construida por el escritor que en principio se presenta como suelta y literal - tiene un valor emblemático y colectivo. Por los temas que aborda, el libro incita asimismo a reflexionar en torno al papel que pueden desempeñar la belleza y el olvido en los procesos de duelo. En lo que sigue evocaremos estos temas situándolos en el marco más general de las letras colombianas e hispanoamericanas contemporáneas que tratan de la violencia en el reciente pasado histórico.

FAMILIA Y NACIÓN

El retrato que el narrador hace de sus padres coincide en varios aspectos con el de las parejas que protagonizan los romances estudiados por Doris Sommer en Ficciones fundacionales. Los romances nacionales de América Latina (2007). ${ }^{3}$ Como esas parejas, Cecilia Faciolince y Héctor Abad Gómez tienen rasgos que, en el contexto colombiano, difícilmente se pueden conciliar. La madre, educada en una familia católica, es profundamente creyente, mientras que el padre es liberal y ateo radical. De manera curiosa, dado lo anterior, ella se deja guiar por firmes aspiraciones feministas mientras que él actúa a veces de manera machista. No obstante estas diferencias y a pesar de la incomprensión de su entorno (74), Cecilia y Héctor se casan, fundan una familia numerosa y son felices.

En las novelas decimonónicas, esas historias de amor que superaban los inconvenientes iniciales pudieron convertirse en romances nacionales debido a que se pudieron leer de manera alegórica, en función de la historia del país en que se ubicaba la trama y del futuro deseado para la comunidad imaginada que representaban. Tal lectura alegórica también la sugiere implícitamente El olvido que seremos, en primer lugar por medio de una serie de paralelismos contrastivos entre familia y nación. En la novela, la historia familiar se presenta estrechamente enlazada con las raíces históricas de Colombia pero, al mismo tiempo, cada faceta de esta contrasta con las elecciones hechas por la familia Abad. Si en la familia se dialoga sin cesar $(94 ; 119)$, las demandas y preguntas que se dirigen al Estado topan con un silencio hostil $(59 ; 218 ; 227)$. Mientras que los parientes se aman incondicionalmente a pesar de, o quizás por, sus diferencias $(79 ; 85 ; 119 ; 186)$, en el país cunde el odio contra quienes disienten (133). Bajo la tutela del padre, la familia abandera la razón (1oo; 225), contrariamente a los grupos paramilitares que, protegidos por ciertas élites económicas y políticas, se dejan arrastrar por la pasión (227). 
Mientras que los parientes apoyan las propuestas a favor de justicia social hechas por el padre poliatra a favor de los más desheredados, las élites se enconan con el statu quo que les permite guardar sus privilegios (50). En fin, el profundo pacifismo y el uso de la palabra por parte de los Abad (38; 217; 235), contrastan con el empleo de la violencia y las armas de fuego de los actores estatales y paraestatales (218).

Entre estos contrastes destacan por su frecuencia los que giran en torno a cuestiones de género, un tema que se aborda desde las primeras páginas de la novela y que se sigue tratando hasta su final. Es conocido el profundo conservadurismo de la sociedad colombiana en materia de género, su admiración hacia la dureza y la falta de sentimentalismo en los hombres y su apego a la subordinación de las mujeres. ${ }^{4}$ Asimismo se conoce la actitud condenatoria de muchos colombianos hacia cualquier comportamiento que transgreda las relaciones heterosexuales. Ahora bien, los padres del narrador se retratan de tal manera que acaban cuestionando de manera radical estas normas. La madre desempeña un papel tradicionalmente delegado en los hombres, ya que crea su propia empresa para que su esposo pueda hablar libremente y, de esta manera, arriesgarse a perder su puesto de trabajo, posibilidad siempre real, pues las opiniones que expresa contra viento y marea pocas veces reciben el visto bueno de sus decanos o rectores $(52 ; 61 ; 120)$. Al revés, el padre presenta características que suelen asociarse con lo femenino, y el narrador admite que la relación que tiene con él se parece a la que sus amigos tienen con sus madres (13). Héctor Abad Gómez es sentimental, expansivo y sumamente tolerante con sus hijos, es incapaz de cambiar un bombillo o una llanta (123) y odia todos los deportes, inclusive el fútbol (145).

Este retrato transgresor llega a su paroxismo cuando el hijo sugiere que su padre parecía sentirse atraído también por los hombres. Una primera alusión no resulta muy clara: "Era al mismo tiempo un sensualista, un amante de la belleza (en hombres y mujeres, en la naturaleza y en las obras creadas por la humanidad)" (124-125). De hecho, su posible significado solo llega a definirse más adelante en la novela: "Creo que sólo un decenio más tarde, después de su muerte, y al escarbar en sus cajones yo llegué a comprender bien lo que mi papá quería que yo viera cuando me llevó a repetir Muerte en Venecia" (240). Por lo tanto, al final del libro el hijo insinúa que su padre se sentía atraído por los adolescentes, pero abandona el tema rápidamente por motivos de discreción (240). En el retrato heterodoxo y lleno de amor que hace de sus padres y especialmente de su padre, se puede leer una condena de la manera en la que en Antioquia se definen las relaciones entre hombres y mujeres. Asimismo, apunta oblicuamente hacia el conservadurismo de la sociedad 
colombiana como una de las causas de la violencia endémica que padece.

Aparte de tejer numerosos lazos de contraste entre la familia y la nación, el poliatra y la polis, la novela también sugiere una lectura alegórica nacional por la manera en la que construye la trama. Desde un punto de vista temático, se puede dividir en dos partes..$^{5}$ La primera se centra especialmente en la familia y termina con el deceso, en diciembre de 1972, de la más alegre, más brillante y más bella de las hermanas, Marta Cecilia, a consecuencia de un cáncer de piel cuando tenía dieciséis años. La segunda parte, que se inicia después de su fallecimiento, trata más de la poliatría del padre y termina con la muerte de este en agosto de 1987. Aunque los separan quince años, los dos funerales se cuentan en el mismo capítulo. Esto sugiere un paralelismo entre ambas muertes de las cuales una es estrictamente un asunto íntimo de la familia y, además, natural, mientras que la otra se relaciona con la nación y es consecuencia de la violenta coyuntura social. Entre ambos decesos surge incluso una relación de causalidad, en la medida en que el hijo afirma que a su padre ya no le importaba mucho seguir viviendo después de la muerte de su hija y que, por esto, empezó a correr riesgos que lo exponían exageradamente a la venganza de sus oponentes: "Creo que hay episodios de nuestra vida privada que son determinantes para las decisiones que tomamos en nuestra vida pública" (188). Por último, cabe señalar que el léxico usado para hablar del país hace que este aparezca como un órgano vivo que está enfermo, por falta de agua limpia (47), por ser un cuerpo mutilado por el cáncer de la intolerancia, corroído por la peste de la violencia $(214 ; 215$; 216), lo cual acentúa aún más las relaciones entre la nación y la familia, que también es representada como un cuerpo por la figura de Marta Cecilia. ${ }^{6}$

Si Sommer califica las novelas que estudia en términos de romances nacionales, también es porque los gobiernos las impusieron en el sistema educativo, esperando que los lectores jóvenes las interpretaran en función de sus propios países en construcción, llenos de conflictos, y que les hicieran confiar en que, como las parejas ficcionales, podrían superar las divergencias internas (casarse) y contribuir a formar comunidades armoniosas y colmadas de bienestar (procrear). De hecho, en aras de una lectura alegórica de la novela, cabe notar que, después de la muerte de Marta Cecilia, los padres no volvieron a hacer el amor (182): es como si de este modo la pareja abandonara su papel ejemplar de contribuir a poblar la nación.

Algunas de las ideas de Sommer también resuenan en el artículo "Estética y narcotráfico" (2008) que Abad Faciolince publicó en una sección de la Revista de Estudios Hispánicos consagrada a la relación entre narcotráfico y estética. Más adelante profundizaremos en este texto, pero 
por ahora nos interesa un párrafo donde compara los semáforos de Colombia con basureros editoriales, porque en ellos se venden "los mafiosos literarios", "los hampones ... dedicados a contar sus fechorías disfrazándolas de hazañas" (516). El autor ataca a quienes están implicados en la publicación de los relatos de la vida de los criminales, textos que tienen mucho éxito comercial en Colombia y que permiten a los asesinos construirse una imagen decente y hasta heroica:

Son libros escritos para lavarse las manos. Y como sus lectores son incultos, en general, no les importa que las justificaciones sean increíbles, ni les sirve de indicio de calidad que la ortografía sea pésima, la redacción disparatada, y la gramática de espanto. Todo forma parte de esa especie de veneración nacional a los violentos que han tenido éxito en su camino pavimentado con muertos. Hay que creerles a los machos que mataron tanto. (516)

Este texto comparte un presupuesto importante con la teoría de Sommer por cuanto implica una declaración de fe en los alcances de la palabra escrita y en los efectos de la lectura cuando se trata de formar la mentalidad nacional: los relatos a los que alude tienen éxito por ella pero de forma inversa y simultánea también contribuyen a perpetuarla. El autor incluso parece conferir más potencial de daño a la palabra que a las armas, lamentando en relación con los asesinos: "Antes había un temor reverencial por sus actos violentos; ahora es peor, ahora se leen con fruición sus palabras" (518). Pero al contrario de Sommer, Abad Faciolince externa un juicio pesimista: los libros que tienen un real lectorado en la Colombia de principios del nuevo milenio exaltan a los criminales; en vez de educar a la paz, sus lecturas fomentan la violencia.

El articulista cierra su diagnóstico con una pregunta retórica a la cual él mismo contesta: " ¿Qué libro serio se vende en los semáforos en este momento? Ya no está ni la basura inofensiva de Coelho, desplazado por los mafiosos literatos" (517). Ahora bien, la respuesta del autor es incompleta o la situación ha cambiado después de que publicase el artículo en cuestión, ya que pudimos constatar a finales del año 2014 que El olvido que seremos se encontraba en muchos puestos callejeros en Bogotá y que, por consiguiente, si su circulación quizás no se estimulaba de manera oficial, sí estaba asegurada en los circuitos de venta más populares. De esta forma, puede que constituya cierto contrapeso y que contribuya a fomentar la tolerancia entre los colombianos, tal y como los gobiernos intentaron hacer en su época al imponer los romances nacionales en el sistema educativo.

El lugar de excepción ocupado por la novela en estos puestos calleje- 
ros, donde se encuentra efectivamente en medio de muchos libros con dudoso valor literario o de testimonios sobre o de los narcotraficantes los libros sobre Pablo Escobar o de Carlos Castaño, el presunto autor intelectual del asesinato de Abad Gómez, son ejemplos - suscita la pregunta de saber por qué esta novela culta ha logrado despertar tanto interés incluso popular. Creemos que la respuesta se encuentra en la belleza del texto y al mismo tiempo en su intención de decir, sin ambigüedad alguna, la verdad de los hechos.

\section{LA DIMENSIÓN ESTÉTICA}

Siendo una autoficción del tipo que Manuel Alberca califica de principalmente autobiográfica y referencial (29), El olvido que seremos supone una doble referencialidad: al mundo externo cuyos eventos reales el autor parece contar de manera escrupulosa, y al mundo literario interno cuya construcción cuidadosa supone inevitablemente cierta fabulación novelesca. Que el escritor se esmera por construir una obra armoniosa se nota desde la estructuración equilibrada de la novela, que se divide en 42 fragmentos. Estos, encabezados cada uno por un número, se distribuyen sobre 14 partes más largas que tienen un título referente a su tema principal. Quizás no sea una casualidad, en un libro que trata de la vida y de la muerte, que sean dos números que se pueden dividir por siete - la cifra que remite al ciclo completo y a la perfección dinámica (Chevalier y Gheerbrant 86o). Asimismo, llama la atención que al padre lo mataran de seis tiros (255) ya que era el grupo de los seis (281) el que en esos años decidía quiénes debían morir por alentar a los "subversivos procomunistas". Tampoco parece un azar que la parte titulada "Dos entierros", donde se relatan los funerales de Marta Cecilia y el padre, sea la séptima. Ya que hay catorce partes en total, no puede ser el centro matemático exacto, sin embargo, su estatus es particular y su sentido central.

El cuidado que se desprende de la estructura de la novela también caracteriza el estilo, que incluye numerosos recursos retóricos. Se nota, por ejemplo, en la repetición anafórica de determinadas expresiones que confieren un tono de letanía al texto, como en las frases siguientes, perfectamente equilibradas, que recuerdan el momento en que el hijo encuentra el cadáver del padre: "Sé que le cojo la mano y que le doy un beso en la mejilla y que esta mejilla todavía está caliente. Sé que grito y que insulto, y que mi mamá se tira a sus pies y lo abraza. No sé cuánto tiempo después veo llegar a mi hermana Clara con Alfonso, su esposo" (257). La voluntad de crear un lenguaje poético también queda patente cuando verbaliza sus sentimientos encontrados mediante una enumeración de 
oxímoron: "En ese momento me invadía una sensación de estupor. Un asombro casi sereno ante el tamaño de la maldad, una rabia sin rabia, un llanto sin lágrimas, un dolor interior que no parece conmovido sino paralizado, una quieta inquietud" (257).

Existe una relación de homología entre la disciplina observada por Abad Faciolince en la confección estructural y estilística de su texto y el objetivo que quiere conseguir al escribirlo: homenajear a un padre para quien la belleza era un valor supremo, que amaba por encima de todo la poesía y la música clásica $(125 ; 131)$ y que, al final de su vida, dedicaba gran parte de sus días no solo a la lucha social sino también a sus rosales (211). Un fragmento de una carta que escribió en 1975 a su hijo decía: "Para mí, paulatinamente, se me va haciendo cada vez más evidente que lo que más admiro es la belleza" (239). Además, le había confesado que le hubiera gustado ser escritor (239), con lo cual El olvido que seremos es un homenaje literario a un escritor en potencia.

Si la creación de belleza puede interpretarse como un homenaje al padre, al mismo tiempo contribuye a mitigar el dolor del hijo. El narrador señala cuan lenitivo es el arte en el proceso del duelo que ha estado atravesando. Para ilustrar el valor terapéutico, el "consuelo paradójico" (241) que brinda la literatura, se refiere a San Juan de la Cruz, Cervantes y Quevedo, que evocan la muerte envuelta en la perfección del arte (241) antes de citar in extensis algunas de las Coplas de don Jorge Manrique por la muerte de su padre. Héctor Abad Gómez las solía recitar de memoria tantas veces que su hijo también se las aprendió, de manera que ahora le sirven de consuelo: "con su perfecta melodía consoladora que se asoma al oído y al pensamiento desde los pliegues más hondos de una conciencia que trata de explicar lo inexplicable" (241).

Al final, cuando los acontecimientos trágicos han ocurrido, el narrador empieza a incluir más afirmaciones autorreferenciales en las que reflexiona sobre el porqué, el cuándo y el cómo redactó sus recuerdos. ${ }^{7}$ En ellas dice qué tipo de estilo quiso privilegiar: "No he escrito en tantos años por un motivo muy simple: su recuerdo me conmovía demasiado para poder escribirlo. Las veces innumerables en que lo intenté, las palabras me salían húmedas, untadas de lamentable materia lacrimosa, y siempre he preferido una escritura más seca, más controlada, más distante" (268). El estilo que optó por usar en su libro coincide con los rasgos de su padre y con los valores de la familia que, como ya hemos dicho, se dejan guiar por la razón y por la mesura (aunque no por la sequedad), lo cual añade una dimensión más específica a la homología entre el objeto del homenaje y el estilo adoptado en éste.

Al dar tanta importancia al control estilístico el narrador se aparta del 
estilo que asocia con quienes están allegados al campo de los asesinos de su padre, al menos es la conclusión a la que se llega al leer el ya mencionado artículo, "Estética y narcotráfico". En este ensayo el autor parte de una pregunta: "¿Asistimos en Colombia a una narcotización del gusto?" (513). Contesta que es falsa la concepción del mafioso como un cuerpo "extraño y maligno incrustado en una sociedad sana" y que, al contrario, el gusto de los mafiosos cundió tan bien en el país porque "el terreno ético y estético estaba aquí abonado" (513). Los mafiosos solo exageran el estilo que ya existe, sobre todo entre los burgueses, los ricos a medias y los nuevos ricos con quienes comparten un mal gusto por el exhibicionismo del dinero, la ostentación de los objetos, el gigantismo y la estridencia truculenta. Con la atracción que sienten estos grupos por lo "grande, ruidoso y estridente", contrastan los calificativos usados por Abad Faciolince en su novela para hablar de su propio estilo: seco, controlado y distante.

Al final del artículo, el autor deplora que la cultura del narcotráfico influya de manera general en la pintura y la literatura nacionales. Sobre esta última dice:

Creo que ciertas figuras sociales creadas por el narcotráfico y cierto gusto mafioso por el lenguaje han influenciado la literatura ... Hay una nueva escuela literaria surgida en Medellín: yo la he denominado la Sicaresca antioqueña. Hemos pasado del sicariato a la sicaresca. Al sicario mismo, inventado por ellos, después lo emplearon, lo siguen empleando otros grupos ... Y lo ha empleado la literatura como nuevo tipo en relatos a veces buenos, a veces horribles, casi siempre truculentos. (515)

Por cuanto desea evitar lo lacrimoso, el estilo de Abad Faciolince se quiere apartar de lo que denomina la "sicaresca" antioqueña, una "escuela" que incluye relatos sobre la violencia que azotó a la sociedad colombiana en las décadas pasadas y cuya calidad es desigual pero que, como dice al final de la cita son "casi siempre truculentos", es decir, morbosos, exageradamente crueles y dramáticos (DRAE). El autor de El silencio que seremos sitúa la truculencia, la estridencia y la sentimentalidad en el campo de los (que mandan a los) sicarios y las atribuye a los escritores de la "sicaresca", mientras reclama para sí mismo un estilo en el que destaquen la razón y el control.

De una manera implícita y en un registro de ficción, Abad Faciolince entra así en un debate que es álgido en el mundo hispánico - y que tiene bastantes parecidos en Colombia, México y España - donde una serie de lectores profesionales procuran definir cuáles son los modos estética y 
éticamente correctos para hablar de la violencia como fenómeno político nacional. ${ }^{8}$ En esos debates críticos y escritores atacan la literatura truculenta: en vez de chocar y apelar al lector, lo adormecen con una serie de estereotipos y tramas sentimentales y, de esta forma, se le hace cómplice del statu quo. Cuando se lee El olvido que seremos en función de estas polémicas, se puede defender la idea de que incorpora la noción de duelo de un modo autorreferencial actualizándolo según dos etimologías diferentes. ${ }^{9}$ Por una parte, el tema del libro es el dolor (dǒlus) provocado por la muerte del padre. Al mismo tiempo y de un modo más oblicuo se encuentran huellas de un duellum, de un mano a mano con escritores que abordan los mismos temas que Abad Faciolince pero sin la dignidad que legitime sus narraciones literaria o moralmente.

UNA CUESTIÓN ÉTICA: LA VERDAD Y LA MEMORIA

En la novela, esta cuestión de la moral suscita una serie de interrogantes sobre la verdad y la memoria. La presencia masiva en el texto de la historia personal del escritor, en combinación con una atención sostenida hacia las necesidades del montaje y hacia la calidad estilística confieren a la novela la ambigüedad propia de la autoficción, con lo cual apunta hacia cierta hibridez genérica postmoderna. Al mismo tiempo, la novela es radicalmente anti-postmoderna por cuanto el narrador no expresa dudas sobre la posibilidad de conocer o de contar la realidad histórica, ni sobre cómo valorarla.

Entre los elementos que sugieren que se trata de una historia verdadera, se pueden mencionar la presencia de personajes con nombres de personas reales - los parientes, amigos y algunas figuras públicas de la escena colombiana -, la inclusión de una serie de citas provenientes de documentos privados encontrados por el hijo en los cajones de su padre o en sus propios archivos personales, y las citas de textos públicos escritos por Abad Gómez para la prensa en los que aboga a favor de una mayor justicia social. Para contar su historia, el narrador también se basa en su memoria personal así como en la de otras personas cuyos recuerdos entrecomilla o evoca en discurso directo o indirecto. En unos pocos casos estos recuerdos vienen acompañados de moduladores que denotan inseguridad en cuanto a su exactitud pero es mucho más llamativo que no se suelan tematizar las posibles fallas de la memoria. ${ }^{10}$ La presencia de testimonios de personas distintas tampoco está al servicio de ningún tipo de perspectivismo relativista porque nunca se contradicen. Al contrario, se completan y se confirman.

La misma seguridad manifestada por el narrador cuando se trata de recordar lo ocurrido, se revela en sus juicios de valor. No se muestra 
indeciso sobre cuál es la verdad y cuál la mentira, ni sobre quiénes son los buenos o quiénes los malos; ni siquiera tematiza estas cuestiones que se presentan como del todo evidentes. En el texto tampoco se insinúa que las víctimas de hecho, tal vez en otras circunstancias o en otro tiempo, hubieran podido convertirse en verdugos, o que estos son a su vez víctimas cuando se miran las cosas desde otra perspectiva. Al revés, toda la novela sugiere que las personas se construyen por sus actos, que son justos o injustos, pacíficos o violentos, por lo cual el autor rehúye cualquier forma de relativismo moral y presenta personajes dignos de elogio o condenados al rechazo del narrador. El análisis del poliatra con el que el narrador hijo parece coincidir (hay pocos temas sobre los cuales disienten), carece tanto de ambigüedad que resulta fácil resumirlo: las élites políticas y económicas se resisten a disminuir las injusticias sociales y las defienden mandando asesinar a quienes quieran introducir cambios o luchar por los derechos humanos (231), después de lo cual, como reacción al sentimiento de desigualdad y a la violencia, surge más violencia (260). Este diagnóstico sobre el pasado reciente, la obra lo integra en una serie de reflexiones relativas a tiempos más remotos, con lo cual acaba por proponer un verdadero sentido de la historia colombiana, como queda ilustrado por el siguiente fragmento en el que el hijo recuerda en un discurso indirecto libre lo dicho y pensado por su padre:

en Colombia crecía de nuevo la epidemia cíclica de la violencia que había azotado el país desde tiempos inmemoriales, la misma violencia que había acabado con sus compañeros de bachillerato y que había llevado a la guerra civil a sus abuelos. Lo más nocivo para la salud de los humanos, aquí, no era ni el hambre ni las diarreas ni la malaria ni los virus ni las bacterias ni el cáncer ni las enfermedades respiratorias o cardiovasculares. El peor agente nocivo, el que más muertes ocasionaba entre los ciudadanos del país, eran los otros seres humanos. Y esta pestilencia, a mediados de los años ochenta, tenía la cara típica de la violencia política. (215)

Al incluir tales pasajes de índole casi didáctica, el narrador no estimula el escepticismo o la duda en el lector sino que busca su adhesión. Para conseguirla, también son relevantes la coherencia de los análisis del padre y del hijo, y el hecho de que se repitan una y otra vez a lo largo del texto. Además, gracias a que el narrador relata su historia personal desde su niñez, comienza por adoptar una focalización algo ingenua, franca y desinteresada (durante todo el relato no dice padre ni madre sino papá y mamá), lo que contribuye a ganar la confianza del lector y hace que creamos más fácilmente en su sinceridad.

Por la manera en la que están construidos los personajes, tal y como 
argumenta Catalina Quesada (218), la novela es totalmente "antisicaresca": al revés de cierta tendencia de la narrativa de los años noventa y dos mil que ennoblece al asesino, Abad Faciolince muestra únicamente su lado oscuro. Pero la novela también es "antisicaresca" por su claridad axiológica en un contexto nacional confuso caracterizado por una profusión de actores -gobierno, militares, paramilitares, guerrillas, narcotraficantes...cuyos intereses intrincados dificultan la comprensión de la situación. Como ha señalado Erna von der Walde, esta dificultad, la sugieren numerosas novelas colombianas: "La multiplicidad de actores en el actual conflicto colombiano y un discurso a través del cual la mayoría de los victimarios se legitima como víctima de la violencia de algún otro, impide hacer el deslinde entre quién es lo uno y quién lo otro" (238). A su vez, María Fernanda Lander apunta que la novela sicaresca, "juega con el agotamiento de significados sobre los cuales los discursos tanto morales como legales sostienen la acusación o el indulto" (168). Estos comentarios afirman que la narrativa sobre la reciente violencia en Colombia no suele distinguir de manera tajante entre culpables e inocentes, o entre campos enfrentados. Leída a la luz de esto, se puede concluir que el duellum que Abad Faciolince emprende en su novela con la sicaresca, además de implicar su rechazo de la estética de lo truculento, también implica un distanciamiento ético de su parte frente a la ambigüedad o el perspectivismo moral. ${ }^{\text {II }}$

Estos rasgos y problemáticas sitúan la novela en el centro de muchos debates relativos a la narrativa hispanoamericana contemporánea. El olvido que seremos comparte una serie de características importantes, tanto de contenido como de forma, con una cantidad considerable de esas novelas. Trata de la violencia en el pasado nacional reciente; enfoca esta violencia política a partir de los efectos que tiene en los individuos y en las familias; procura recuperar hechos silenciados por el poder; presenta un narrador que cuenta en primera persona y utiliza el formato de la autoficción. No obstante, el uso que hace de las formas para hablar de sus temas confiere a la novela un estatuto peculiar. Por una parte, en cuanto a los personajes, las novelas históricas hispanoamericanas del pasado reciente, por ejemplo la narrativa del crimen, a menudo incluyen personajes ambiguos, desdibujan las fronteras entre inocencia y culpabilidad o insinúan que los culpables lo son por su pasado o por el sistema, lo cual hasta cierto punto los redime. Frente a estas tendencias, resaltan la claridad de los juicios éticos y la índole dicotómica de los personajes en la novela de Abad Faciolince. Por otra parte, un importante corpus de novelas hispanoamericanas recientes recurren al género autoficcional (Alberca; Logie) o son contadas en primera persona por 
narradores no fiables (Saban; Vanden Berghe). La autoficción y los narradores no fiables se emplean entonces con vistas a llamar la atención sobre las dificultades de tener acceso a la realidad por la índole escurridiza de esta, sobre el problema de conocer la verdad del pasado por el transcurrir del tiempo que lo deforma, o sobre la imposibilidad de contar los acontecimientos verazmente por el carácter propio de la lengua que influye en su construcción. En la medida en que presenta su verdad sin fisuras, El olvido que seremos es muy diferente de este tipo de novelas. También se particulariza puesto que no problematiza la memoria, tema que se presenta bajo numerosas facetas.

\section{MEMORIA LITERAL Y MEMORIA EJEMPLAR}

En su breve ensayo titulado Los abusos de la memoria, Tzvetan Todorov se propone buscar nuevas categorías respecto al tema de la memoria que sean más adecuadas que las oposiciones tradicionales, por ejemplo entre olvido y memoria, un tema sobre el cual volveremos. Quiere "fundar la crítica de los usos de la memoria en una distinción entre diversas formas de reminiscencia" (32-33), al diferenciar de manera concreta una lectura literal de otra, ejemplar, de los acontecimientos pasados. La primera se basa en el principio de la contigüidad, la segunda en la semejanza; la primera desemboca en el sometimiento del presente al pasado, mientras que la segunda permite utilizar el pasado con vistas al presente. La memoria literal permanece intransitiva y no conduce más allá de sí misma, contrariamente a la memoria ejemplar, de la que Todorov dice:

Sin negar la propia singularidad del suceso, decido utilizarlo, una vez recuperado, como una manifestación entre otras de una categoría más general, y me sirvo de él como de un modelo para comprender situaciones nuevas, con agentes diferentes ... abro este recuerdo a la analogía y a la generalización, construyo un exemplum y extraigo una lección. $\left(33^{-} 34\right)^{12}$

Al final de su libro, Abad Faciolince empieza a desarrollar reflexiones sobre el tema del recuerdo que se acercan a las preocupaciones de Todorov.

El hecho de que la narración se centre en la persona más amada por el narrador y además se cuente desde perspectivas íntimas hace que El olvido que seremos se presente en primer lugar en función de una experiencia individual e incomparable, una memoria literal. Así lo sugiere Abad Faciolince cuando equipara su obra con una carta a su padre: "Este libro no es otra cosa que la carta a una sombra" (22). La circunstancia de que el narrador circunscriba su reflexión al ámbito nacional sin duda refuerza el carácter literal de su memoria. Además, la situación no parece haber 
mejorado, sino degenerado: "Sus asesinos siguen libres, cada día son más y más poderosos" (268); "No dudo de que haya algunos, hoy también, que tengan deseos de 'anularles el cerebro' a personas como Alberto Aguirre y Carlos Gaviria" (284). Mientras que Todorov presenta ejemplos en los que el pasado sirve de lección al presente - "El pasado se convierte por tanto en principio de acción para el presente" (34) - y que, por consiguiente, son representativos de una memoria ejemplar, en El olvido que seremos la relación entre el pasado y el presente implica más bien contigüidad que semejanza y parece encerrar el asesinato en su literalidad.

La historia contada suscita tantas emociones en el narrador que le resulta sumamente difícil tomar distancia de la índole literal de la misma, aunque quisiera hacerlo:

Su caso no es único, y quizás no sea el más triste. Hay miles y miles de padres asesinados en este país tan fértil para la muerte. Pero es un caso especial, sin duda, y para mí el más triste. Además, reúne y resume muchísimas de las muertes injustas que hemos padecido aquí. (269)

El fragmento ilustra la tensión que se instala en el texto al respecto, como se deduce de la repetición del sintagma, "el más triste" en el que el superlativo apunta al carácter singular y a la índole insuperable de la experiencia. ${ }^{13}$ En la primera frase "no es el más triste", el narrador cuestiona la unicidad o la excepcionalidad del crimen, mientras que la segunda aparición del superlativo, esta vez afirmativa, la restaura. Pero en ambas frases la índole respectivamente ejemplar y literal de la experiencia es modulada en el sentido contrario: "quizás" relativiza la ejemplaridad y "para mí" implica una operación parecida sobre la literalidad. La sucesión de las frases hace ver una misma tensión, ya que incluye un vaivén entre las dos memorias, empezando por "no es único", pasando por "pero es", hasta volver a la afirmación de la ejemplaridad cuando la palabra "muchísimas" retoma la idea de la falta de unicidad presente en la expresión "miles y miles".

Otros indicios en el texto demuestran que el narrador es consciente de la necesidad de abandonar la parálisis inherente a la memoria literal. Asumir una actitud positiva le cuesta, así afirma, porque le invaden la nostalgia, el rencor y la amargura. Por ello se obliga a pensar en los años de completa dicha vividos por la familia: "Para no caer en la nostalgia dulzona ni en el resentimiento que todo lo tiñe de desolación, basta decir que en Cartagena pasábamos un mes entero de felicidad..." (136). Sigue una frase larguísima que recuerda muchas actividades que garantizaban este mes de felicidad, frase a la que acompañan a su vez distintos capítulos sobre los 
largos años felices. De hecho, buena parte de la novela se centra en la vida de la familia y el amor que unía a los parientes, y aunque el asesinato del padre se anuncia desde el inicio y vuelve como un leitmotiv, sería exagerado decir que es el único tema del texto o siquiera el principal desde el punto de vista cuantitativo. En otras palabras, el esfuerzo hecho por parte del narrador por recordar y dejar masivamente constancia de los momentos felices forma parte de un aprendizaje por convertir su memoria literal en otra ejemplar, y esto convierte al libro en un testimonio poco común sobre la felicidad. Como dijo Adolfo Castañón: "Es un libro que huele a felicidad y a fragancia de rosas" (117).

Pero es el propio hecho de ponerse a escribir el que acaba por garantizar la verdadera conversión. Lo que Abad Faciolince cuenta sobre algunos objetos del padre que había guardado, como la camisa que llevaba cuando lo mataron, permite ilustrarlo:

No sé por qué la guardaba. Era como si yo la quisiera tener ahí como un aguijón que no me permitiera olvidar cada vez que mi conciencia se adormecía, como un acicate para la memoria, como una promesa que tenía que vengar su muerte. Al escribir este libro la quemé también pues entendí que la única venganza, el único recuerdo, y también la única posibilidad de olvido y de perdón, consistía en contar lo que pasó, y nada más (237). ${ }^{14}$

La cita da cuenta de una evolución en el narrador, en quien el deseo de venganza se ha transformado con el proceso de escritura - "al escribir este libro" - en la conciencia de que lo que debe hacer es recordar, olvidar y perdonar. De nuevo recurre al léxico de la salud, esta vez para hablar de la acción de escribir, que es a la vez condición y consecuencia de su sanación: "Escribo esto en La Inés, la finca que nos dejó mi papá, que le dejó mi abuelo, que le dejó mi bisabuela, que abrió mi tatarabuelo tumbando monte con sus propias manos. Me saco de adentro estos recuerdos como se tiene un parto, como se saca un tumor" (266). ${ }^{15}$ Escribir es catártico hasta tal punto que en las últimas líneas del libro la memoria adquiere una índole verdaderamente ejemplar. Entonces el narrador sale al encuentro de los lectores que puedan reconocerse en lo expuesto:

Y si mis recuerdos entran en armonía con algunos de ustedes, y si lo que yo he sentido (y dejaré de sentir) es comprensible e identificable con algo que ustedes también sienten o han sentido, entonces este olvido que seremos puede postergarse un instante más, en el fugaz reverberar de sus neuronas, gracias a los ojos, pocos o muchos, que alguna vez se detengan en estas letras. (288) 
El narrador no se limita aquí a dirigirse a los lectores colombianos o a quienes fueron a su vez víctimas de crímenes políticos sino que comparte su memoria, "mis recuerdos", con quienesquiera que seamos los lectores, desde dondequiera que leamos o cualquiera sea la experiencia que nos permita reconocernos en la novela. Esto acaba por presentar su memoria como eminentemente ejemplar. ${ }^{16}$

Al terminar su libro, el narrador-escritor ha atravesado una etapa importante de su duelo ya que se ha curado a sí mismo y ha evolucionado hacia una memoria ejemplar. ¿Eso lo convierte en un poliatra, a semejanza de su padre? Si consideramos que "decir la verdad" sobre el pasado y "declarar la injusticia" (268) del presente tienen un valor terapéutico para la sociedad, no cabe duda de que el hijo se ha hecho cargo de la herencia paterna. Y debido a que en esta novela no hay manera de separar ética y estética, también puede considerarse una forma de poliatría la propuesta de una alternativa al gusto mafioso por lo grandilocuente y para el estilo truculento de la "sicaresca".

EL OLVIDO

Cualquiera sea la forma que la memoria pueda revestir, es un bien poco común en Colombia, como apunta el narrador en varias ocasiones. En el entierro de su padre, a pesar del clima de terror que reina, algunos amigos toman la palabra. Entre ellos, el novelista antioqueño Manuel Mejía Vallejo aprovecha la ocasión para criticar la facilidad con que se olvida como una característica sobresaliente del país: "Vivimos en un país que olvida sus mejores rostros, sus mejores impulsos, y la vida seguirá en su monotonía irremediable, de espaldas a los que nos dan la razón de ser y de seguir viviendo" (260). El juicio es respaldado por el narrador que, cuando busca en google un artículo de otro amigo de su padre, lamenta que no haya nada al respecto: "Eso se está olvidando, aunque no hayan pasado demasiados años" (280). Sugiere además que la sobreabundancia de información tiene su cuota de responsabilidad en este panorama ya que hace que, lo que de verdad importa, no logre tener la visibilidad que merece. ${ }^{17}$ El encubrimiento del asesinato de Abad Gómez y su rápida relegación posterior a los archivos (254) es el culmen de este tipo de olvido que consiste en una operación ideológica de parte de un Estado que suprime lo que no le conviene que se siga recordando. Se trata de un proceso que, en el contexto del pasado reciente del Cono Sur, Idelber Avelar ha llamado "olvido pasivo", "esa clase de olvido que se ignora a sí mismo, sin advertir su condición de producto de una poderosa operación represiva" (284). Contrasta con el olvido activo que Avelar asocia con la "tarea del duelo" (284) y que, a nivel individual, es un proceso inevitable e incluso positivo. ${ }^{18}$ 
Por su parte, también Todorov llamó la atención sobre la índole natural de ese proceso: "La memoria, como tal, es forzosamente una selección: algunos rasgos del suceso serán conservados; otros, inmediata o progresivamente marginados y luego olvidados" (18). En tal caso, el olvido no se opone a la memoria, sino que es a la vez simultánea y posterior. Estas ideas de Avelar y Todorov resuenan en la novela. Así el narrador considera que su libro es una "prótesis de la memoria" y lo describe como un intento de posponer el olvido inevitable: "Solamente mis dedos, hundiendo una tecla tras otra, pueden decir la verdad y declarar la injusticia. Uso su misma arma: las palabras. ¿Para qué? Para nada; o para lo más simple y esencial: para que se sepa. Para alargar su recuerdo un poco más, antes de que llegue el olvido definitivo" (268). Concibe su libro como una manera de lentificar el proceso del olvido pero al mismo tiempo considera que éste ayuda en el proceso del duelo, escribir es "el único recuerdo, y también la única posibilidad de olvido y de perdón" (237). ${ }^{19}$ La conjunción "y también" y la construcción paralela indican que entre recuerdo y olvido no mide ninguna brecha insalvable.

La idea de que el olvido puede ser lenitivo también está implícita en el título El olvido que seremos, que es el primer verso de un poema que el narrador encontró en el bolsillo de su padre muerto. Comienza así: "Ya somos el olvido que seremos. / El polvo elemental que nos ignora / y que fue el rojo Adán, y que es ahora, / todos los hombres, y que no veremos" (251). Y termina con la reflexión siguiente: "Pienso con esperanza en aquel hombre / que no sabrá que fui sobre la tierra. / Bajo el indiferente azul del Cielo / esta meditación es un consuelo" (251). En la medida en que destaca la faceta positiva del olvido, el poema apoya la valoración hecha por el propio narrador.

En 2010, cuatro años después de El olvido que seremos, Abad Faciolince publicó Traiciones de la memoria, un volumen que incluye tres relatos autoficcionales. En el primero, titulado "Un poema en el bolsillo", el narrador, otro doble del autor, vuelve a hablar del poema. Por razones que ya no le son muy claras en 2010, en 1987 estaba convencido de que su autor era Borges, y así lo dijo cuando lo publicó por primera vez pocos meses después del asesinato de su padre. Pero sólo cuando postuló esta autoría en El olvido que seremos la cuestión comenzó a suscitar polémicas, ya que algunos le acusaron de atribuir el poema a Borges para vender más ejemplares de su libro (Traiciones 27). ${ }^{20}$ Sea como fuere, en "Un poema en el bolsillo" Abad Faciolince cuenta las peripecias que le llevaron a creer sin fallas en la autoría del escritor argentino y de este modo el relato se convierte en una especie de postdata a la novela.

No obstante, un cotejo entre El olvido que seremos y Traiciones de la 
memoria revela dos cambios significativos. El primero consiste en que, en el libro posterior, se reconocen los límites cuando se trata de recordar el pasado. Este reconocimiento, que ya se desprende de su título, se repite en el propio texto. Primero, lo hace el autor en el prólogo donde afirma: "Si miro hacia atrás y trato de recordar los hechos que he vivido, los pasos que me han traído hoy hasta aquí, nunca estoy completamente seguro de si estoy rememorando o inventando" (11). Después, en el primer relato, es el narrador quien reconoce que su memoria es imperfecta e, incluso, va a celebrar este hecho: "Cada vez estoy más convencido de que una memoria solamente es confiable cuando es imperfecta, y que una aproximación a la precaria verdad humana se construye solamente con la suma de los recuerdos imprecisos, unidos a la resta de los distintos olvidos" (130).

Otro cambio trascendente frente a la novela se deduce de un comentario incluido en el segundo relato del volumen, titulado "Un camino equivocado". En él el narrador reconoce que es complicado distinguir en el ámbito nacional colombiano de manera clara entre varios grupos de personas: "Era difícil, muy difícil de explicar quiénes eran los buenos y quiénes eran los malos en Colombia, donde - a diferencia de las películas de vaqueros - todos los malos tienen algo de buenos, y donde a todos los buenos, tarde o temprano, se les sale su ladito malo" (205). Desde esta perspectiva, el libro de relatos se va incluyendo en una tendencia de la literatura hispanoamericana contemporánea que hemos señalado antes, y se va acercando a la narrativa colombiana tal y como es presentada por von der Walde y Lander. Pero sobre todo, al matizar axiológicamente a los personajes, la puerta hacia la reparación y el perdón, que empezaba a abrirse paulatina y dificultosamente en El olvido que seremos, en Traiciones de la memoria se abre de par en par.

Université de Liège

NOTAS

1 La versión inglesa de la novela añade un subtítulo que consiste en una información remática explícita, calificando el libro en términos de memorias: Oblivion. A Memoir.

2 Es un rasgo importante de la obra narrativa de Abad Faciolince (Quesada 216).

3 Publicado originalmente en inglés en 1993.

4 Entre otras muchas alusiones a esos valores, al principio de la obra el narrador cuenta que sus amigos se burlaban de cómo él y su padre se saludaban efusivamente: "Un saludo entre machos, padre e hijo, tenía que ser distante, 
bronco y sin afecto aparente" (23). Otras personas tampoco veían con buenos ojos la relación que se establecía entre padre e hijo: "Algunos de mis parientes decían que mi papá me iba a volver marica de tanto consentirme" (34).

5 El propio narrador apunta a esta división cuando dice: "Y ahora tengo que contar la muerte de Marta, porque eso partió en dos la historia de mi casa" (158).

6 Notemos aquí que Abad Faciolince utiliza desde una posición contraria metáforas a menudo empleadas por los militares en distintas partes de América Latina para lamentar que la nación estuviera enferma y para decir que había que curarla con métodos radicales.

7 La presencia de aspectos metaficcionales es otra constante en la obra del escritor antioqueño (Quesada 212).

$8 \quad$ Para debates parecidos acerca de la narrativa española se puede consultar Rosa. En cuanto a las discusiones en México es ilustrativa la polémica entre Parra y Lemus.

9 Retomo la idea de Geneviève Fabry quien articula su estudio sobre Juan Gelman en torno a ella.

10 Al narrador la única incertidumbre que lo incomoda es no saber quiénes son exactamente los autores intelectuales del asesinato de su padre. Sin embargo, no duda en qué campo debe buscarlos (222; 265). Luego, en una sola ocasión el libro tematiza el problema de la memoria: "La memoria es un espejo opaco y vuelto añicos, o, mejor dicho, está hecha de intemporales conchas de recuerdos desperdigados sobre una playa de olvidos" (144). Pero esta cita se encuentra algo aislada en medio de una gran cantidad de afirmaciones del narrador que dice recordar bien lo que pasó. Por lo tanto, la obra no participa en ninguna poética ilusionista o escéptica. En este sentido no concordamos con Fanta Castro, para quien el libro presenta una "verdad compuesta de grietas" (38).

" Hacia el final de la novela, se incluyen unas afirmaciones que borran un poco las oposiciones tajantes. En ellas, el hijo admite que su padre a veces cerraba indebidamente un ojo cuando las atrocidades eran cometidas desde la izquierda política. Hasta cierto punto hace que se entienda el enojo de sus asesinos: "Lo cual nunca podrá justificar su asesinato, pero puede explicar en parte la ira asesina de quienes lo mataron" (234).

12 El ejemplo que propone consiste en el caso extremo del simpatizante comunista David Rousset que pasó por un campo nazi de Buchenwald y que, a pesar de esta experiencia traumática e incluso debido a ella, considera que tiene el deber de condenar también los campos estalinistas (46).

13 Así también lo ve Todorov: “Cuando se habla de una cualidad 'singular', lo que ha sido visto más a menudo es, en realidad, una cualidad superlativa: se afirma que es el mayor y el peor crimen de la historia de la humanidad" (41; énfasis en 
el original), lo cual implica que es incomparable. Después dice con ironía: "lo cual, dicho sea de paso, es un juicio que no puede resultar más que de una comparación".

14 Si aquí contar es la "única manera", después se transforma en un "deber" (267) y una "necesidad" (268).

15 Según Andrea Fanta Castro, "el libro entero pareciera ser la lucha por evitar narrar el brutal acontecimiento" (30), pero "En una especie de catarsis, Abad Faciolince quizás pudo haber reconocido la muerte para que la repetición de la escena, nunca vista, cesara. Y simultáneamente, sin que implique una contradicción, el enterrar esas imágenes a través de la escritura es una manera de situarla, hacerla presente en cada instante, en todo momento, en la medida en que se actualiza constantemente en cada lectura" (37).

16 En este punto nuestro análisis coincide con el de Fredy Leonardo Reyes Albarracín que estudia la novela en función del tema memoria/historia.

17 Esto ya había enfurecido a su padre cuando supo el mismo día de su muerte que acababan de matar al presidente del gremio de maestros de Antioquía: “Al mediodía de ese martes, cuenta mi mamá, volviendo juntos de la oficina, mi papá quiso oír las noticias sobre el crimen de Luis Felipe Vélez, pero en todas las emisoras de radio no hablaban de otra cosa que de fútbol. Para mi papá el exceso de noticias deportivas era el nuevo opio del pueblo, lo que lo mantenía adormecido, sin nociones de lo que de verdad ocurría en la realidad, y así lo había escrito varias veces" (250). Este juicio, que ya habíamos leído antes en La virgen de los sicarios, donde el cínico narrador afirmaba: "El muerto más importante lo borra el siguiente partido de fútbol” (Vallejo 40), coincide también con el de Tzvetan Todorov que, en Los abusos de la memoria, apunta a la misma sociedad de ocio como responsable de la sobreabundancia de información que, a su vez, garantiza el olvido: “[S]eparados de nuestras tradiciones, embrutecidos por las exigencias de una sociedad del ocio y desprovistos de curiosidad espiritual así como de familiaridad con las grandes obras del pasado, estaríamos condenados a festejar alegremente el olvido y a contentarnos con los vanos placeres del instante. En tal caso, la memoria estaría amenazada, ya no por la supresión de información, sino por su sobreabundancia" (17).

18 Todorov adopta la misma idea: "Otra forma de marginación de los recuerdos se produce en el duelo: en un primer momento, nos negamos a admitir la pérdida que acabamos de sufrir, pero progresivamente, y sin dejar de añorar a la persona fallecida, modificamos el estatuto de las imágenes, y cierto distanciamiento contribuye a atenuar el dolor" (27).

19 Ver al respecto también Ricoeur.

20 Esto ilustra que es difícil que un texto que trate de la violencia reciente no se vea involucrado en debates éticos que atañen a cuestiones comerciales. 
OBRAS CITADAS

ABA D FA CI O LIN CE, Héct or. El olvido que seremos. Barcelona: Seix Barral, 2014.

-. Traiciones de la memoria. Madrid: Alfaguara, 2010.

—. "Estética y narcotráfico". Revista de Estudios Hispánicos 42.3 (2008): 513-518.

ALB E R A, MANUE L. El pacto ambiguo. De la novela autobiográfica a la autoficción. Madrid: Biblioteca Nueva, 2007.

A V E L A , I D L B E R. Alegorías de la derrota: la ficción postdictatorial y el trabajo del duelo. Santiago de Chile: Cuarto Propio, 2000.

CAST AÑ Ón, A D OL F O. "Sobre un memorial de Héctor Abad Faciolince: El olvido que seremos". Revista Universidad de Antioquia 293 (2008): 114-118.

CHEVAlier, JeAn y alain GHEERBRAnt. Dictionnaire des symboles: mythes, rêves, coutumes, gestes, formes, figures, couleurs, nombres. París: Robert Laffont, 1995. FABRY, G ENEVIÈVE. Las formas del vacío. La escritura del duelo en la poesía de Juan Gelman. Amsterdam/Nueva York: Rodopi, 2008.

FANT A CASTRO, AN DREA. "Imágenes del tiempo en El olvido que seremos de Héctor Abad Faciolince". Letral 3 (2009): 28-40.

LANDER, MARía FERnAn Da. "La voz impenitente de la 'sicaresca' colombiana”. Revista Iberoamericana 73.218 (2007): 165-177.

LEMUS, RAFAEL. "Balas de salva. Notas sobre el narco y la narrativa mexicana”. Letras Libres (septiembre 2005): 39-42.

—."Música de despedida. Alegato con delirio". Letras Libres (noviembre 2005): 5859.

LOGIE, ILSE. "Más allá del 'paradigma de la memoria': la autoficción en la reciente producción postdictatorial argentina. El caso de 76 (Félix Bruzzone)".

Pasavento. Revista de Estudios Hispánicos 3.1 (2015): 75-89.

PARRA, EDUARD O AN TON IO. "Norte, narcotráfico y literatura". Letras Libres (octubre 2005): 60-61.

QUES ADA, CA T A lin A. "Héctor Abad Faciolince (Colombia, 1958)". The Contemporary Spanish-American Novel. Bolaño and After. Eds. Will H. Corral, Juan E. de Castro y Nicolas Birns. New York: Bloomsbury, 2013. 212-219.

REYES A LBARRACín, FREDY LE ONARDo. "El olvido que seremos y Mi confesión: testimonio, memoria e historia”. Revista Comunicación y Ciudadanía 4 (2010): 24-30.

Ricoeur, PAul. La mémoire, l'histoire, l'oubli. París: Seuil, 2000.

ROSA, IS A AC. "Memoria literaria y represión franquista". La recuperación de la memoria histórica. Una perspectiva transversal. Coord. Gonzalo Acosta Bono, Ángel del Río Sánchez y José María Valcuende del Río. Sevilla: Centro de Estudios Andaluces, 2007. 159-168.

SABAN, KA RE N. Imaginar el pasado. Nuevas ficciones de la memoria sobre la última dictadura militar argentina (1976-1983). Heidelberg: Winter, 2013. 
SOM M ER, D O R IS. Ficciones fundacionales. Las novelas nacionales de América Latina.

Trad. José Leandro Urbina y Ángela Pérez. Bogotá: Fondo de Cultura

Económica, 2007.

To d o R ov, TZVET A . Los abusos de la memoria. Trad. Miguel Salazar. Barcelona: Paidós, 2013.

Vallejo, Fernand o. La virgen de los sicarios. Madrid: Punto de lectura, 2006.

VANDEn beRGHE, KR IS Tine. “¿Quién mató a Rosario Tijeras? Narco y culpa”.

Bulletin of Spanish Studies 92.2 (2015): 2-19.

VON DER WALDE, ERNA. "La novela de sicarios y la violencia en Colombia".

Iberoamericana 1.3 (2001): 27-40. 